\title{
FORUM
}

Submitted 09.11.2017. Approved 12.26.2017

Evaluated through a double-blind review process. Guest Scientific Editors: Marina Heck, Jeffrey Pilcher, Krishnendu Ray, and Eliane Brito

Original version

DOI: http://dx.doi.org/10.1590/So034-759020180309

\section{HAWKERPRENEURS: HAWKERS, ENTREPRENEURSHIP, AND REINVENTING STREET FOOD IN SINGAPORE}

\author{
Hawkerpreneurs: Vendedores ambulantes, empreendedorismo e reinvenção da \\ comida de rua em Singapura
}

\author{
Hawkerpreneurs: Hawkers, iniciativa empresarial y la reinvención de la comida \\ callejera en Singapur
}

\begin{abstract}
The hawker center is an icon of contemporary Singapore and an essential element of national identity, but one that has undergone multiple reinventions. Most recently hawking has repeatedly been presented as approaching crisis, prompted by an aging hawker population. The response of the Singapore government has been to begin another historic transformation of the hawker, focusing on the hawker entrepreneur - the hawkerpreneur. Ahead of reinvention, codification of knowledge about hawking was required and provided by museum exhibitions and cultural celebrations in media. The hawker became romanticized, a figure of history, distanced from an emergent next generation. These new hawkers are imagined by public and private interests as being successful entrepreneurs and glamorous, suit-wearing people. A change in status for hawking, achieved by a new image and structural changes, such as rankings by Michelin, are being used to signal this new phase of Singaporean street food.
\end{abstract}

KEYWORDS | Singapore, hawkers, hawkerpreneurs, street food, reinvention.

\section{RESUMO}

O hawker center (centro de vendedores ambulantes) é um ícone da Singapura contemporânea, um elemento da identidade nacional singapurense que passou por muitas reinvenções. Recentemente, a presença de vendedores ambulantes tem sido representada repetitivamente como uma crise próxima, causada pelo envelhecimento da população de ambulantes. A resposta do governo singapurense tem sido outra transformação histórica, direcionada do vendedor ambulante ao empreendedor ambulante - o hawkerpreneur. Antes da reinvenção, a codificação do conhecimento sobre vendedores ambulantes foi necessária e provida por exibições em museus e celebrações culturais em várias mídias. O ambulante torna-se romantizado, uma figura histórica, distanciada da próxima geração emergente. Empreendedores ambulantes estão sendo educados, assim como o público. Esses novos ambulantes são imaginados, pela iniciativa pública e privada, como empreendedores de sucesso, pessoas de estilo, bem-vestidas e glamorosas. As mudanças no status dessa categoria, alcançadas não apenas por uma nova imagem, mas também por mudanças estruturais, tais como ranqueamentos pela Michelin, estão sendo utilizadas para sinalizar essa nova fase do mercado de comida de rua singapurense.

PALAVRAS-CHAVE / Singapura, vendedores ambulantes, hawkerpreneur, comida de rua, reinvenção.

\section{RESUMEN}

El hawker centre (patio de comida) es un ícono de la Singapur contemporánea, un elemento esencial de la identidad nacional de Singapur, pero que ha pasado por múltiples reinvenciones. Más recientemente, el hawking (comercio en patios de comida) ha sido repetidamente representado como una crisis inminente, provocada por una población de hawkers (comerciantes en patios de comida) que envejece. La reacción del Gobierno de Singapur ha sido comenzar otra transformación histórica del hawker concentrándose en el emprendedor hawker (el hawkerpreneur). Un paso al frente de la reinvención, la codificación del conocimiento sobre hawkers y hawking era requerida y proporcionada por muestras de museo y celebraciones culturales en diversos medios. El hawker es idealizado, una figura histórica, distanciada de una próxima generación emergente. Los hawkerpreneurs están siendo educados como el público. Los intereses públicos y privados imaginan estos nuevos hawkers como emprendedores exitosos, gente bella, bien peinada, de traje y glamorosa. Un cambio de status para el hawking, logrado por una nueva imagen, pero también por cambios estructurales tales como rankings de Michelin, que se están usando para señalizar esta nueva fase de la comida callejera en Singapur. PALABRAS CLAVE / Singapur, vendedores ambulantes, hawkerpreneurs, comida callejera, reinvención.

\section{NICOLE TARULEVICZ}

nicole.tarulevicz@utas.edu.au ORCID: 0000-0002-9884-5057

Humanities, Hobart, TAS, Australia 


\section{INTRODUCTION}

The hawker center is an icon of contemporary Singapore and an essential element of national identity. But in recent years, as an aging hawker population vanishes into the sunset, this icon of inexpensive, tasty, multiethnic, and hygienic street food has been repeatedly represented as approaching crisis. The Singapore government, having already reinvented the hawker in the 1960 s and moving them from the street to the hawker center, is responding again to this possible crisis. The government, working together with private actors, has begun yet another historic transformation of the iconic hawker, and this time a key emerging element is the new hawker entrepreneur, or "hawkerpreneur."

Taking inspiration from the 2017 Hawker Centre 3.0 Committee Report, this article first contextualizes the hawkerpreneur by tracing historic reinventions of Singaporean street food and the contours of the reported hawker center crisis, then turns to this new Singaporean figure. Using the language of the report, with its numerical framing of 3.0 representing the present, a clean periodization is imposed, erasing some of the necessarily blurry boundaries of periodization. It is not the lived experience of hawkers that is the focus of this paper, but rather it is hawking at a discursive level. While state actors, colonial and post-colonial, have had loud voices, non-state actors have also shaped how hawking is understood. Different actors "speak" in different mediums - from legislation, reports, speeches, photographs, magazine articles, and awards - but these varied forms can work in tandem.

If we think of these disparate sources not as lone acts of communication but as forms of culinary infrastructure, we can see how ideas about hawkers have fared, as well as served ideological, economic, and nationalist functions. For Pilcher (2016), culinary infrastructure includes both material components (traditional infrastructure like roads, ports, and technologies) and embodied expressions of knowledge (recipes, cooking practices, health regulations) and extends to "knowledge infrastructure of media and social networks that create and transfer cultural meanings about food" (p. 5). As I have argued elsewhere (Tarulevicz, 2016, p. 133), informal bodies of popular knowledge are also infrastructure. Thinking about both popular and official hawker knowledge usefully illustrates how they are formed, and highlights some of the cultural work they do. The figure of the hawkerpreneur provides us with a pertinent example of the extension of culinary infrastructure into the realm of ideology.

Singapore is a small, densely populated island nation connected by a causeway to Johore in Malaysia. The population of five million, including transient foreign workers, occupies just $704 \mathrm{~km} 2(272 \mathrm{mi} 2)$. Singapore is multi-religious and multiracial; a Chinese majority ( 76 percent) coexists with Malay (15 percent), Indian (8 percent), and in the words of the state, "Other" (1 percent) minority communities. Identity is further complicated by categories, such as Peranakan and Eurasian. Since 1966 official designations of race have been determined by state categories used in the National Registration Identity Cards, regardless of lived experience (Velayutham, 2017).

Singapore's transition from a British East India Company trading post to an independent "Asian Tiger economy," has been accompanied by massive economic growth facilitated by its status as a free port and consequent access to complex networks of peoples, goods, and trade. Those complex networks also created flows in labor and demand for cheap food to feed workers, many of whom had no access to cooking facilities, or to the labor of family members to cook for them. That demand was met by hawkers, itinerant street vendors selling simple meals, cooked and uncooked foods, snacks, and beverages (Warren, 1986). Hawkers and hawker food, played a critical role in building the economy of Singapore. While celebrated today in contemporary Singapore as preserving a national cuisine and culture, hawkers have undergone multiple reinventions and have been viewed historically as both a necessity and a problem.

\section{Hawkers 1.0: On the Street, 1819-1967}

Both a necessity and a nuisance, hawkers were an unruly industry to administer, unclean, and perceived to be prone to breaking regulations in pursuit of profit. The first attempts at regulating street food had limited success, and the period 1819-1967 (Hawker 1.o) can be characterized by street food on the street in a disordered fashion. Hawkers produced waste and were classed by their occupation. As the psychoanalyst Dominique Laporte (2000) notes, waste must be regulated for fear of disease and social contamination. The historian Shah's (2001) work on the Chinese in San Francisco reminds us of this connection between literal and social contamination and the ways that it can be raced and focused on specific occupations. Public health and attempts at regulation of bodies and spaces has long been central to the colonial project.

Singapore, an important free port, was a transit zone. Hawkers, moving through these transient populations, were at the center of anxiety about the spread of disease. As a port city, Singapore was particularly vulnerable. It was not just a node in an imperial network; it was part of other networks, 
including important religious and cultural flows in the Indian Ocean. For Willis (2017), the management of bodies during the Hajj highlights the deep connection between control of bodies and colonialism. Travel from Southeast Asia to Mecca during the Hajj posed, as Tagliacozzo (2013) notes, specific public health concerns. For colonial officialdom, street food hawkers, connected to these varied nodes, were a discursive problem of disorder and dirt.

For Chakrabarty (1992), discourse about public health and hygiene is connected to modernity because "it is the language not only of imperialist officials but of modernist nationalists as well" (p. 541). In Singapore, both colonial and postcolonial officials have used regulations about public health and hygiene as a way of bringing order to disorder. The regulation of hawkers can be understood as part of broader attempts of ordering and cleaning the city and the citizenry. A range of private and mercantile groups, acting in tandem with these public interests, were looking to shape street food in various ways.

In October 1872, a riot involving hawkers, particularly cooked-food vendors, broke out in Singapore. The police had been officiously enforcing regulations, introduced in 1860 , intended to improve sanitary conditions and the flow of traffic by preventing congregation of hawkers and spontaneous nightmarkets. In the inquiry that followed, Senior Magistrate of the Straits Settlement, Mr. F. Snowden, expressed his opinion "that the police did oppress these hawkers" (Colonial Office, 1872, p. 246). In his report, Mr. R. A. Irving, Assistant Colonial Secretary, described the notice issued by the Inspector General (in English and Chinese, and distributed by Chinese constables):

Notice is hereby given that it is not the intention of the Government to interfere with people selling things in the street except with reference to men setting up stalls in the public thoroughfares and causing obstruction. If any considers that he has been ill-treated by the Police, and will lay the complaint before the Inspector General the matter will be enquired into. (Colonial Office, 1872, p. 247).

Significant here is the use of the phrase "the Government." The riot had moved from being a policing matter to a Straits Settlement matter. Specifically questioned on this issue, Irving was at pains to clarify that his actions, including supporting the issuing of the notice and calling out the military, were "on the part of the Executive, as a representative of the Executive, at the request of the Inspector General, and on the advice of the other Officers of the Government" (Colonial Office, 1872, p. 247). The riot was thus considered as a matter of colonial government concern, as opposed to a local police matter.

How hawking was central to the riot is less clear. As historian Melissa Macauley has shown, the riots were connected with rural pacification in China. Chinese witnesses to the riot testified that events in Chaozhou underpinned the riot. Chinese merchants "insisted that the hawkers themselves had played little role in the violence, and that most of the rioters had been samsengs (fighting men) not hawkers who took advantage of resentment amongst the hawkers" (Macauley, 2016, p. 770). For the administrators on the ground, rioting hawkers, whether or not they were hijacked by samsengs, needed to be controlled, as well as pacified. The system of itinerant hawking, always popular with residents, was unpopular with colonial officials, despite its acknowledged utility.

As useful as hawking was, it could undermine public health and was subject to regulation. Diseases, including cholera and typhoid, were particular concerns. Contaminated water used by stalls was a source of water-borne diseases, whether the water was dispersed on the ground or used in mixed drinks. Diseases also spread through inadequately cleaned hands and utensils. Hawkers were understood to be carriers of gastroenteritis, enteric fever (typhoid), dysentery, cholera, and parasitic infections, such as hookworm and roundworm. Food waste from stalls drew insects and rodents, and the tropical conditions of Singapore increased the rate of decay and spread of contamination. Itinerancy itself was also a problem (Tarulevicz, 2015 , p. 6), making hawkers a vector for the spread of disease through their own movement and through the movement of their waste across multiple areas.

Itinerancy made regulations about cleanliness and attempts to clean public spaces a Sisyphean task. Streets could spontaneously become night markets if enough hawkers congregated. Certain areas would regularly attract these informal night markets. During these periods of occupation, tasks such as street cleaning became more difficult. Town cleaning laborers consequently avoided these areas. If they did not, they clashed with the hawkers. The legal status of hawking varied, with certain practices (such as congregating) being a continual source of tension between authorities and the public.

Schumpeter (1942) identified the process of "creative destruction" as an "essential fact about capitalism" that "incessantly revolutionizes the economic structure from within, incessantly destroying the old one, incessantly creating a new one" (p. 83). In the dying days of the British colonization of Singapore, getting rid of the itinerancy component of hawking 
was the main objective, the creative destruction. In destroying the form (street food), the cuisine itself was preserved. A key component of this creative destruction shifted the focus from the practice of hawking on to individual hawkers. The strategies for regulation also shifted toward individual embodied strategies, much more akin to other public health strategies.

The 1950 Hawker Inquiry Commission reflected this shift, noting that "the presence of any hawkers makes it difficult to keep streets clean, but it is chiefly the hawkers of food and drink that do the harm" (Hawker Inquiry Commission, 1950, p. 2). Hawking became a matter of public health, and the commission sought advice from the Municipal Health Department. Out of this consultation, the commission recommended that all hawkers be compulsorily inoculated against typhoid, and that as a condition of holding a license, hawkers be required to submit to a medical inspection by municipal health inspectors. The commission also suggested the introduction of straws to raise the standard of hygiene and recommended they be made available, even if doing so required a subsidy. In removing a potential point of contact with dirty bodies and equipment, the commission evoked a mechanism for bringing about better health outcomes.

The Hawker Inquiry Commission both destroyed and preserved hawking in Singapore. It played a major role in the eradication of itinerant hawkers, although a systematic regulatory regime was not introduced until Singapore was fully independent. The commission also acknowledged the centrality of hawking to the Singaporean way of life, and, as geographer Kong (2007, p. 19) suggested, the decision to regulate rather than prohibit hawkers was a major shift in colonial administrative thinking. By laying the foundation for moving hawkers into controllable spaces, the commission actually preserved it, albeit in a modified form.

\section{Hawkers 2.0: Hawker Centers, 1968-2016}

In the first decades of Singaporean independence, hawking was transformed from chaotic to ordered, and the itinerant sellers who walked the streets came under increased regulation in indoor spaces. The first hawker centers were relatively basic, purpose-built structures that had running water, electricity, and a roof, but were open at the sides, pavilion style. Sited predominantly in residential areas and in the city, the centers aimed to replace the services provided by itinerant vendors and housed permanent stalls, as many as 60 . These stalls, like their cart predecessors, specialized in specific dishes or cuisines and sold a limited range of items. Over the years, some hawker centers have become more elaborate spaces or food centers, often integrated with malls (Chua, 2016, p. 24). Contemporary hawker and food centers might be recognizable as a cousin of food courts, a tastier and less corporate cousin, but still related. As infrastructure, the transformation from itinerancy to hawker centers required a bureaucracy (an army of inspectors), a legal apparatus (empowering police and inspectors), and a shift in popular knowledge. Certain gustatory changes accompanied this movement (Duruz, 2016, p. 144). Satay cooked indoors, for example, might actually be safer than that cooked at a hawker cart, but the taste and eating experience (a sea breeze versus air-conditioning) has changed, and satay is now understood as street food even when not cooked or eaten on the street.

The regulation of food provision and the remaking of public space can be seen across the food sector. Hawkers, once seen as unseemly, dirty, and visceral, were cleaned up, their hands washed, their cooking equipment inspected and standardized. The places where they plied their trade were eradicated, repurposed or replaced with "ordered" spaces - hawker centers. In turn, these spaces were increasingly policed, made cleaner and orderly at every turn. Duruz and Khoo (2015) describe Singapore's hawker centers as existing at the "intersection of charm and safety" (p. 99). Such ordered spaces produce cleaner and safer foods, reinvented for a new era and expectations.

\section{The vanishing hawker}

The most recent transformation of hawkers relates to their status. Having built up hawkers and hawker centers as quintessential to Singaporean culture, a crisis is now being staged about their future. A 2015 article asked, "Is Singapore's hawker culture faltering?” (Malay Mail Online, 2015). The problem was articulated as "the street food culture here is in danger of fading into the sunset. Why? Because older hawkers are retiring or passing away, and there is not enough new blood to take their place,". Hawking is repeatedly represented as being in crisis and common themes emerge around age and desirability of the career. Tan Hsueh Yun, a Straits Times journalist, sums up the crisis and argues that it must evolve in order to survive:

The median age of hawkers here is 59 years [...] Scores of them have retired and many more continue to do so every year. Young people make more money blogging or writing listicles about hawker food than they ever will running a hawker 
stall. Why slave in a cramped and hot hawker stall when you can make pronouncements on the five best Hokkien mee stalls in Singapore on a laptop? (Straits Times, 2016).

Generational change and expectations about profit and the nature of work are common themes in the hawking crisis. A desire amongst younger hawkers to do new things, such as making fusion foods, also arises; the crisis is in part about keeping the hawker culture traditional but simultaneously allowing it to evolve. Peter Mok, a new hawker, laments that “(Old-style) hawkers are dinosaurs, society will evolve and they will no longer be found. The hawker culture will change with the changing tastes of the newer generation" (Malay Mail Online, 2015).

In museum exhibitions and cultural celebrations in media, the vanishing hawker represents a paradoxically strong, if romanticized figure. To illustrate this, I discuss two examples, a book and an exhibition (that also includes a guidebook), which exemplify recent visual representations of hawking. Hawking has never been exclusively male, and the representations of the vanishing hawker are not exclusively male either. They do tend, however, to echo those elements of the Hawker 1.0 era where some activities - cooking over flames, selling alcohol skewed male.

Not for sale: Singapore's remaining street food vendors is a private archival project supported by the National Heritage Board (2013) and headed by Angelia Teo, Bernie Guan, and Sinma DaShow, who describe the project as "a private odyssey, for the three of us - local "lads" who having lived overseas, returned to find the vast changes going on at home." Starting in 2010, the project ran for 900 days and included photographs from over a hundred hawker centers, thousands of hours of interviews, recordings, and transcriptions. Public expressions include a book, a Facebook page, media coverage, and YouTube interview footage.

Predominantly composed of striking black and white photographs, the book of $300+$ pages also include text, color images, and quotes from hawkers. The book uses a variety of narrative techniques that represent hawkers as dying and exhausted, with skills and tradition on the verge of being lost, and also shows the struggles of older generations requiring recognition before they vanish. Having inscribed hawking as a vanishing tradition, however, the book works to make space for hawking to be re-inscribed as a site of potential and growth - that is, the nostalgia for its vanishing demise is an essential element in its reinvention. Not for sale's foreword by MP Baey Yam Keng, Chair of the Government Parliamentary Committee for
Culture, Community and Youth, is explicit about the importance of hawking to Singapore:

Singapore hawker food is an integral part of our national identity. It binds Singaporeans from all walks of life and provides shared memories and experiences across generations [...] We must be proactive in preserving, protecting and promoting our local food culture. This book seeks to record and celebrate hawkers and stalls with the longest history and heritage, and accord them with recognition and the status of national heritage food. This is indeed a worthy project highlighting valuable work in an area close to all our hearts. (National Heritage Board, 2013, p. 10.)

Baey is comfortable that private archiving is concomitant with government views and the purpose of this celebration is programmatic: "we need to recognize and respect the dedication of these artisan hawkers. Only then will younger people be motivated and aspire to join this trade" (National Heritage Board, 2013, p. 11). The logic is clear - recognition will elevate the status of hawkers and make it appealing to the next generation. This builds on a symbolic demarcation between old-style hawkers and the next generation. In part, Not for Sale does cultural work to lock down the old-style hawker. Most obviously, the black and white photography frames the separation between oldstyle and contemporary, fixing these celebrated hawkers and their stalls in the past.

Baey's optimistic tone is not carried deeper into the book. The first chapter ("No Regrets") begins in a funereal tone with an image of a locked, wall-mounted medical box, from a now-closed hawker center. The letters HELP (which identify the function of the kit) have been repurposed to read "Hawker Emergency Life Saving Point." The tone is mirrored in the opening text:

Our subjects told us they have no regrets, doing what they have done for most of their lives... Most stalls are almost certain of vanishing altogether with their owner's age. And far be it from us to consider this chapter a eulogy of their life's work, let it stand as a record of the history they created (National Heritage Board, 2013, p. 19)

The eulogy aspect is further emphasized with a quotation from Saint Augustine: "No eulogy is due to him who simply does 
his duty and nothing more" (National Heritage Board, 2013, p. 19). These hawkers are due a eulogy. They are being celebrated for having done more than their duty and for being extraordinary. But they are relegated to history, their time passed into the past. Following this opening section of the book, are 45 pages of captioned photographs.

Portraits of hawkers and their stalls are interspersed with images of culinary objects reiterating the past, such as a fullpage photograph of a washed metal pot with strainers entitled: “A pot emptied of its broth" (National Heritage Board, 2013, p.54). The portraits capture place and people, almost conflating the two, with the stall and the hawker inseparable. Many of the images are bleak, such as the one of Tan Huang Khiang (II), framed by hanging meat and looking exhausted in his beef noodles stall. We are told that at age 13, he started helping his father and that before they had a stall they had a pushcart. His exhaustion is underscored by a quotation: "I'll work until I can't carry on. I'm getting slower every day because of my age" (National Heritage Board, 2013, p. 37).

For Singaporeans, this is a historical narrative. References to age and slowing down, when read in tandem with the physical signs of tiredness (and in black and white) cast this as historical. Since most Singaporeans were born after independence (post1965, when itinerant hawking was outlawed), a hawker who began his working life selling food from a pushcart is describing a moment known only through the narrative forms of history. Further references to past practices reinforce the message. Phoon Hon Sun, who runs a roasted duck and meats stall, started out in 1969 and shares memories of practices very different from contemporary Singapore: "I remember watching over our food carts through the night for fear of raids by health inspectors" (National Heritage Board, 2013, p. 22). This implied relationship between hawking, crime, and the Singaporean state sounds unworldly and alien, locating this hawker in a culturally distant past.

Having killed and buried hawking in the past, the remaining chapters of Not for Sale begin to hint at a resurrection. “Fables \& Tales," for example, works to separate hawkers from the now by emphasizing that traditions are vanishing and techniques becoming lost. For example, Nai Kim Siong, a drinks hawker, is quoted: "We are fast losing our coffee traditions. We used to roast our own beans and toast our bread over charcoal grills" (National Heritage Board, 2013, p. 82). Yet the level of detail - roasting and toasting - positions the work as skilled and thus artisanal, foreshadowing themes directed at the next generation of hawkers. Handmade food is emphasized too, as in Koh Jee Kok: "Our curry puffs are fresh and they are handmade.
Handmade food comes with a special attachment" (National Heritage Board, 2013, p. 94). Handmade, literally made by hand rather than machinery, works like artisanal to give food a high status and oppositional to mass-produced, industrial foods (Blundel and Smith, 2013). Handmade signifies skilled labor, not just labor, which is a way of celebrating these hawkers and signaling to the next generation that although this career is hard work, it is skilled, not manual work.

Similarly, the autonomy associated with hawking both emphasizes the past and hints at the future. Prawn noodle hawker Lau Fook Wah, for example, says: “My father's thinking was always better to be your own boss than an employee, even if you were a 'kachang puteh' seller, you would still be better off” (National Heritage Board, 2013, p. 84). (Kachang Puteh, a snack food of steamed and fried nuts, spiced or sweetened, was sold by itinerant sellers, packaged in paper cones traditionally made from newspaper.) Sim Han Boo, a fishball noodle stallholder, illustrates the hawking promise of economic autonomy: "I first started out in this trade as a stall assistant before running my own stall to earn my living" (National Heritage Board, 2013, p. 109). Emphasizing autonomy, progress, and skilled artisan labor again foreshadows the reinvention of the hawkerpreneur.

Siblings Loh Choon Huay and Loh Kai Mong explain why they took over their mother's stall: “... we wanted to keep our mother's craft and taste alive" (National Heritage Board, 2013, p. 180). Fixing taste, while not possible, has a certain appeal in Singapore, a nation in which change has been both rapid and profound. Haley (2012) reminds us that it is hard to capture the taste of the past because "it is not just our minds that play tricks with us, but also our bodies. Food is familiar and history often is not. Like kids at the candy store window, we can almost taste the past" (p. 78). Instead, as Fitzgerald and Petrick (2008) note, we use historical imagination to "approximate the nature of taste historically" (pp. 392-393). Yet it is impossible, as Amy Bentley (2014) reminds us, to "return to a historical moment and sample food as it existed at the time, or to recreate a product's taste as it was experienced within a particular historical and cultural milieu" (p. 82). When the Lee brothers say of their roast duck and meats stall, "there are no changes to the way we prepare our food, if we change then it is not our food anymore" (National Heritage Board, 2013, p. 235), we cannot assume that the taste is fixed. After all, when their grandfather started the stall almost 60 years ago, the conditions of production of ducks was quite different from today. Promoting timelessness in a sea of change provides comfort, roots the practice in the past, and does some of the same work as emphasizing craft: it elevates manual labour to artisanal labour. 
Not for Sale ends with "Afterthoughts" and an image of two exhausted male hawkers resting, heads on the plastic hawker center table, feet up, shoes off and on the seats, mugs of beer untouched. A blank page entitled "My personal memories" implicates the reader - here is where memories should be noted. The reader has worn out the hawkers and must take some responsibility. Singaporeans are familiar with such appeals. The National Archives have encouraged Singaporeans to "grab their tape-recorders" and capture memories of their elders "before it is too late" and deposit the recordings (National Archives, 2002, p. 1). Food writer Oon (1998, p. 7) echoed this approach and said she wished to inspire Singaporeans to "reach out for pen and paper" to capture family recipes and find "their own cultural soul." Memory-making is both personal and national work in Singapore (Tarulevicz, 2013, p. 110).

This conflation of the personal and the national is also evident in a recent exhibition celebrating one of the first hawker centers, the Taman Jurong Market and Food Center, another site of the codification of knowledge about hawkers and hawking. Using Taman Jurong as its focus, the exhibition and accompanying guide Eat: Our hawker centers and food heritage (2016) periodizes the hawker era. This guide (over 100 pages) weaves a conventional narrative of national progress into the story of multi-redevelopments of a specific site. Painting life as harsh in the colonial era, the guide emphasizes the provision of infrastructure by the State and the gradual improvement in the working and living conditions of hawkers and of Singaporeans.

During the hawker 2.0 era, hawker centers emerged as spaces that had national and social value: "[hawker centers] became more than just places for people to eat their meals, they became social spaces where family and friends gathered to spend time together, and hawkers and customers interacted with each other daily," (Eat: Our hawker centers and food heritage, p. 30). In the 2016 iteration of Taman Jurong, social space is emphasized and children's drawings of what social space means to them are included in the design.

Much of the Eat volume is dedicated to recollections from hawkers who worked in particular versions of the hawker centers in Taman Jurong. The last section of the book focuses on the retirement of these hawkers and the ensuing crisis. Illustrating how this genre of history works, the Taman Jurong exhibition encodes knowledge about hawkers of the past by tracing the histories of specific sites, connecting those to national history, periodizing these histories, and finally connecting this knowledge with the life-stories of individual hawkers. Ang Soo Kwang, a second-generation hawker, is identified as encapsulating "the whole essence of being a hawker," when he says "... I feel that the most important thing is to cook with sincerity. When you feel good and cook with all your heart, this emotion will be conveyed to the customers who eat your food" (Eat, 2016, p. 109). Casting vanishing hawkers as symbols of the past both romanticizes hawker virtues and emphasizes the idea that that their replacement is part of wider historical processes, which works to affirm what Slotkin (1973) would see as narratives of progress. With practices and aesthetics codified and richly described, the vanishing hawker was ripe for reinvention.

\section{Hawkers 3.0: Hawkerpreneurs}

Food vendors may share characteristics reflective of the constraints and appeal of the business of selling food. Broadly speaking, food vending has been open to the marginal and has historically reflected migration patterns, ethnic and racial makeup, and social and economic position (Ray, 2016, p. 12). Because of specialization and scale, relatively less capital is required for hawkers than other food businesses. By offering a limited range of foods, ingredient, equipment, and labor costs are lower. These structural aspects of hawking - accessibility, smaller financial and cultural capital requirements, employment without a boss - all work to make this a field ripe for innovation, driven by changes in image and status.

The academic concept of an "entrepreneur" has a notably tangled history. In a classic article, Gartner (1988) insists that entrepreneurs create organizations, but he is less interested in the study of entrepreneurial traits. In the Singaporean context, the emergent and distinctive figure of the hawkerpreneur is popularly associated with little else but the personal characteristics of the next generation. Entrepreneurs have played a critical role in the national story of Singapore as they have in many consumer capitalist countries. Culinary entrepreneurs, however, are especially noted in Singapore. For example, kopitiams (small coffee shops selling drinks and light meals), are important to Singapore's foodscape but also to its entrepreneurial history (Lai, 2012, p. 221).

Ah Koon, a classic example of a kopitiam entrepreneur, started the Ya Kun Kaya Toast brand. As Andrew Tam points out, the narrative "of a hardworking man from humble origins serving homemade toast and coffee [...] is crucial to the Ya Kun Kaya Toast brand" (Tam, 2017, p. 50). In a written history of the company, this connection between individual life story and company is repeatedly emphasized (Koh, 2010). Yeo Thian In, the founder of Yeo Hiap Seng soy sauce brand, provides another example of a traditional culinary entrepreneur whose life story 
of humble beginnings, adversity, and eventual prosperity define the genre (Yeo, 2010). Soy sauce production and coffee shop chains, while different kinds of businesses, share a similar entrepreneurship narrative. What is clear is that hawkerpreneurs are not entrepreneurial hawkers; they are entrepreneurs who have become hawkers. Theirs is not the story of a single, male migrant who worked hard, overcame adversity to build a business from scratch, and the business then became an empire. Rather, it is the story of a successful entrepreneur who turns his or her attention to hawking.

In early 2017, the Hawker Center 3.0 Committee, a team of public servants, citizens, and interested parties chaired by Dr. Amy Khor, Senior Minister of State, Ministry of Environment and Water Resources, submitted its report. Tasked with developing proposals to improve hawker centers and promote trade, the Hawker Centre 3.0 report detailed strategies for the reinvention of the iconographic Singaporean street food cuisine (Government of Singapore, 2017, p. 5). The report made 11 key recommendations to sustain the hawker trade, support new entrants, improve productivity, enhance hawker center spaces, and "promote graciousness."

One interesting recommendation of the committee was for greater food curation in hawker centers. Echoing the language of museums and art galleries, this form of curation ensures a good mix of foods is available in all hawker centers and "the retention of traditional hawker food where appropriate" (Government of Singapore, 2017, p. 38). Curation, however, also discourages ethnic enclaves, thus mirroring housing policy where each building must reflect the ratio of ethnic groups in Singapore (Sin, 2002, p. 287). In fact, Tam suggests that hawker centers, as public social spaces, were "deliberately constructed to reverse racial segregation" by facilitating racial integration through the provision of multiracial foods in one place (Tam, 2017, p. 47).

A critical part of the revitalization included the training of potential hawkers. Contemporary Singapore's highly competitive and stratified education system, used to reinforce ideals of Singaporean meritocracy, has emerged as a key industry. The island nation is consciously trying to position itself as the "Boston of the East" with a hub of universities and a current international student body of 75,000 , from primary to tertiary (Tan, 2016). It comes as no surprise that hawkers are also the subject of education. One strategy, "an incubation stall programme," allowed aspiring hawkers to experience running a stall for six to 12 months under the guidance of mentors (Government of Singapore, 2017, p. 7). Establishment of a resource center with information about licensing, paperwork, and regulations was also proposed.
Specific training schemes recently gained great popularity: one food management hawkers program, for example, received sixty applications for eighteen places. Private providers also play a role, such as the Singapore Hawker Entrepreneur Program, which runs a 15 -hour training program covering matters from selecting a location to food safety certification requirements (Singapore Hawker Entrepreneur Program, n.d.). Thus far, these schemes have not proved successful in the long term. Only five of the 46 trainees, who graduated from Dignity Kitchen's Hawker Master Trainer Pilot Programme, are still in the hawking business one year from graduation (Lee, 2016).

Elevating the status of hawkers is a concern of the report and also of hawkers themselves. The Straits Times quoted Philip Tan, a 59-year-old hawker of fish ball noodles, who suggested a name change: "Instead of using the word hawker, we should use another term, in the same way bus drivers are now called bus captains" (Straits Times, 2016). A new image is even more important than a new name. Luxury lifestyle magazine, Peak, featured seven stalls with 12 next-generation hawkers, "Shaping the Future of Singapore Food," who reflect the new hawker image:

A young woman bravely sat her father down for a firm talk about who's boss. Two brothers gave up good degrees in IT and engineering to flip dough. Still others sacrificed sleep and personal time to sweat it out over a hot stove. Their stories are here. And they stem from one thing: passion. (Koh, 2016).

The young hawkers have common themes - they were all successful in something else before they chose to become hawkers. What is critical in this narrative is that they had high status positions already (engineers, marketing specialists) and chose to leave those to become hawkers. Joel Chia was a "sharp-suited foreign exchange trader working 'short and sweet' hours at a local bank," who gave that lifestyle up for the long hours and physicality of working in a curry rice stall. Sebastian Kwek's story gives additional culinary gravitas to hawking - he worked in respected European restaurants before taking over his grandmother's pulled noodle stall. Kwek chose a hawker stall over a prestigious restaurant, but the entrepreneur turned hawker also emphasizes the business advantages of this: "if these ideas fail, I will lose just a bit of money [...] So, if it works, good. If it doesn't, at least I gave it a try" (Koh, 2016).

This 3.0 generation also presents well - a hawkerpreneur is noticeably fashionable. The hawkers represent the three main 
ethnic groups of Singapore - Chinese, Malay, and Indian - and these are beautiful people, coiffured, suited, and glamorous. They look like they would be more at home in a fashion shoot than a busy hawker stall. Echoing the images in Not for Sale, the photographs in Peak evoke the past, but a very different, glamorous one, with vintage-tinged design elements hinting at 1930s Shanghai cocktail lounges and classic Bollywood. And, unlike the vanishing hawker, these photographs are sharp and in full color, with the textures of the tweeds clearly visible, and clothing labels carefully noted for fashion-conscious readers.

A hawkerpreneur can be rugged as well as fashionable. Habib Mohamed, who runs an Indian Rojak (mixed chopped salad) stall, is photographed next to a case of redolent vegetables and fritters, like a Bollywood star in his silver suit. He tells how hard he worked, including covering for a staff member suddenly called away for a number of weeks. In the language of Peak: "But tough times don't last - only tough men do." Hawking is hard work and not for the faint-hearted. Brothers Mohamed Dufail and Almalic Faisal make their popular prata by hand, kneading flour and fat in large batches to make a special bread, crisp on the outside, soft in the center. This is craft, described as "the magic that happens when the dough is tossed by deft hands," inducing customers to queue for 30 minutes or more. That it takes time frustrates some customers, but as Mohamed says, “This isn't McDonald's” (Koh, 2016).

These hawkerpreneurs represent the opposite of industrial-scale food production. Three siblings from the Sai family work at the intersection of traditional methods and modern coffee aesthetics. They make coffee using the traditional sock method but also offer lattes, using traditional kopi techniques and ingredients, such as evaporated milk. Faye Sai notes that some customers expect a latte to come from an espresso machine: "Sometimes, people peek inside our shop when they order a latte and try to look for a machine. And then I'll get very angry. You don't need (machine-pulled) shots to do a latte" (Koh, 2016). This next generation is both innovative and adaptive, able to negotiate tradition and techniques to emphasize old and new craft.

Hawkerpreneurs are both artisans and innovators. Gwern Khoo and Ben Tham started their first hawker stall with "a premium rendition" of a local staple, wonton noodles. Making this a high-end dish was initially seen as a novelty, but winning a Bib Gourmand award in 2016 helped "A Noodle Story" to develop a cult following and international status. With restaurant experience under international chefs, such as Tetsuya, the pair consciously brought fine-dining restaurant techniques to street food, making only 200 bowls a day of "thin springy noodles, tender slices of 36-hour sous vide char siew, wonton made from fresh Indonesian minced pork, and half an egg with a molten yolk" (Koh, 2016). Sous-viding the char siew (Chinese style barbeque pork) immediately locates the dish in a restaurant space. Their customers are cosmopolitans too - not the average Singaporean, who is locally referred to as a heartlander (Goh, 1999). Khoo notes: “[...] our customers are mostly office executives. They are well-travelled, eat more widely, are more receptive to new creations and are willing to pay for quality" (Koh, 2016).

Structural changes in status have been critical to the reimagining of hawking. Singapore was the first Southeast Asian nation to be rated by the Michelin Guide, and in 2016 (the first year of rating) several hawker stalls were awarded Michelin stars (Henderson, 2017). Systems of awards are a clear form of culinary infrastructure, moving beyond its traditional focus on fine dining. The significance of this was not confined to the individual hawkers; the mere possibility of winning a Michelin star elevated the status of hawking as a profession. Coiffured, suit-wearing, beautiful people, dedicated to craft could now receive international recognition and prestige in line with their status as existing entrepreneurs.

The Michelin winners, however, were actually of the old-school hawker variety. Chan Hon Meng, owner of Hong Kong Soya Sauce Chicken Rice and Noodle, for example, has been a hawker for 35 years. A short film produced by Michelin tells Chan's story. The aesthetics of the film, including soundtrack, are very reminiscent of the film Jiro Dreams of Sushi, produced by Iwashina and Pellegrini (2011), linking Chan with the story of 85-year-old Jiro Ono, sushi master and owner of a 10-seat, three-Michelin-star restaurant in a Tokyo subway station. These are older Asian men who are masters of their art. Chan is humble. When he received the invitation to attend the Michelin gala dinner he was "uncertain", and "I asked them, 'Are you joking? Why would Michelin come to my stall?” His humbleness is not just about his food but his status as a hawker. He said to the Michelin representative: “'I've never heard of Michelin inspectors visiting a street stall, can even a hawker be nominated?" (Michelin Guide Singapore, 2016). That question, “can even a hawker be nominated?" speaks directly to the issue of transformation of status. For the next generation to want to be hawkers, hawking needs to have a high status, and Michelin awards provide this.

Chan's narrative explains how this transition works: "For us chefs we long for the day we are recognized internationally. It is a form of honor. As if we are in university and now graduating." By casting the award in terms of education and honor, Chan 
is translating the award into culturally recognizable forms. In a society that emphasizes education and meritocracy (Barr \& Skrbiš, 2008, p. 60), this narrative framing especially suits a Singaporean audience. Chan suggests that chefs and hawkers cook as if every plate of food were being tasted by a Michelin inspector (Michelin Guide Singapore, 2016). For hawkers, cooking as if being judged by the world makes the act of food preparation competitive, demanding, and worthy, further working to elevate the status of hawking.

\section{CONCLUSION}

Street food is understood in multiple ways, including as a cuisine and byword for local food. In contemporary Singapore, it is also a shorthand for nation. Together, hawking and hawker food do significant cultural and social work in Singapore, in particular around belonging and identity. Spatial reflections of identity, from street food to coffee shops (Lai, 2016, p. 103), have occupied scholars, as has the rise of culinary nostalgia. Hawker centers are the quintessential eating spaces of Singapore, and as Kong (2007, p. 19) suggests in her book on hawker centers, these are places that "have mirrored the changing life and landscape in Singapore over time."

Singapore has undergone remarkable transformation with potentially disorienting speed. The island's geographic territory has expanded through land-reclamation and its built environment is subject to perpetual redevelopment with inevitable social and technological changes. Commentator George (2000, p. 193) suggested that the rate and scale of change affects the Singaporean psyche because "even if they stay put, the country moves around them, and Singaporeans find themselves eventually in a new place, clinging only to ghosts". Hawkers are being made into ghosts through redevelopment, codification of the past, and reinvention. But they have been entrepreneurial and reinvented before. Whether the coiffured generation will become the next hawkerpreneurs, time will tell.

\section{REFERENCES}

Barr, M., \& Skrbiš, Z. (2008). Constructing Singapore: Elitism, ethnicity and the nation-building project. Copenhagen, Denmark: NIAS Press.

Bentley, A. (2014). Inventing baby food: Taste, health, and the industrialization of the American diet. Berkley, CA: University of California Press.
Blundel, R. K., \& Smith, D. J. (2013). Reinventing artisanal knowledge and practice: A critical review of innovation in a craft-based industry. Prometheus, 31(1), 55-73. doi:10.1080/08109028.2013.770276

Chakrabarty, D. (1992). Of garbage, modernity and the citizen's gaze. Economic \& Political Weekly, 27(10-11), 541-547.

Chua, B. H. (2016). Taking the street out of street food. In L. Kong, \& V. Sinha (Eds.), Food, foodways and foodscapes: Culture, community and consumption in post-colonial Singapore (pp. 23-40). Singapore: World Scientific.

Colonial Office. (1872). British Colonial Records, 275/16.

Duruz, J. (2016). The taste of retro: Nostalgia, sensory landscapes and cosmopolitanism in Singapore. In L. Kong, \& V. Sinha (Eds.), Food, foodways and foodscapes: Culture, community and consumption in post-colonial Singapore (pp. 133-158). Singapore: World Scientific.

Duruz, J., \& Khoo, G. C. (2015). Eating together: Food, space and identity in Malaysia and Singapore. Lanham, MD: Rowman and Littlefield.

Eat: Our hawker centers and food heritage. (2016). Singapore: National Heritage Board.

Fitzgerald, G. J., \& Petrick, G. M. (2008). In good taste: Rethinking American history with our palates. Journal of American History, 95(2), 392 404. doi:10.2307/25095625

Gartner, W. B. (1988). Who is an entrepreneur? Is the wrong question. Entrepreneurship Theory and Practice, 12(4), pp. 11-32. doi:10.1177/104225878901300406

George, C. (2000). Singapore: The air-conditioned nation; Essays on the politics of comfort and control, 1990-2000. Singapore: Landmark.

Goh, C. T. (1999, August 9). National day speech: First-world economy, first-class home.

Government of Singapore. Ministry of the Environment and Water Resources. (2017). Hawker Centre 3.o Committee Report. Retrieved from https://www.mewr.gov.sg/Data/Editor/Documents/HC\%203.0\%20 Report.pdf

Haley, A. P. (2012). The nation before taste: The challenges of American culinary history. The Public Historian, 34(2), 53-78. doi:10.1525/ tph.2012.34.2.53

Hawker Inquiry Commission. (1950). Report of the Hawkers Inquiry Commission. Singapore: Singapore Government.

Henderson, J. (2017). Street food, hawkers and the Michelin Guide in Singapore. British Food Journal, 119(4), 790-802. doi:10.1108/BFJ-10-2016-0477 
Iwashina, K., \& Pellegrini, T. (Producer), \& Gelb, D. (Director). (2011). Jiro Dreams of Sushi [Film]. Provincetown, MA: Magnolia Pictures

Koh, M. (2016) Next generation: 12 young hawkers shaping the future of Singapore food. Retrieved from http://thepeakmagazine.com.sg/ gourmet-travel/next-generation-12-young-hawkers-are-shaping-thefuture-of-singapore-food/.

Koh, W. (2010). The top toast: Ya Kun and the Singapore breakfast tradition. Singapore: Cengage.

Kong, L. (2007). Singapore hawker centres: People, places, food. Singapore: National Environment Agency.

Lai, A. E. (2016). The Kopitiam in Singapore: An evolving story about cultural diversity and cultural politics. In L. Kong, \& V. Sinha (Eds.), Food, foodways and foodscapes: Culture, community and consumption in post-colonial Singapore (pp. 103-132). Singapore: World Scientific.

Lai, A. E. (2012) The Kopitiam in Singapore: An evolving story about migration and cultural diversity. In L. A. Eng, F. L. Collins, \& B. Yeoh (Eds.), Migration and diversity in Asian contexts (pp. 209-231). Singapore: Institute of Southeast Asian Studies Publishing.

Laporte, D. (2000). A history of shit. N. Benabid \& R. el-Khoury(Trans.), translation Cambridge, MA: MIT Press,

Lee, G. S. (2016). Few hawkers still in business after apprenticeship programme. Retrieved from http://www.channelnewsasia.com/news/ singapore/few-hawkers-still-in-business-after-apprenticeship-programme-8188882.

Macauley, M. (2016). Entangled states: The translocal repercussions of rural pacification in China, 1869-1873. American Historical Review, 121(3), 755-779. doi:10.1093/ahr/121.3.755

Malay Mail Online (2015, Oct. 29). Is Singapore's hawker culture faltering? Retrieved from http://www.themalaymailonline.com/print/eatdrink/is-singapores-hawker-culture-faltering

Michelin Guide Singapore (Producer). (2016). The Michelin guide insider series: The story of Chan Hon Meng. Available from https://www. youtube.com/watch?v=_1dBTqm9oA4

National Archives of Singapore. (2002). National Archives of Singapore. Brocher, Singapore, National Archives.

National Heritage Board. (2013). Not for sale: Singapore's remaining heritage street food vendors. Singapore: The Academy.

Oon, V. (1998). A Singapore family cookbook. Singapore: Pen.

Pilcher, J. (2016). Culinary infrastructure: How facilities and technol- ogies create value and meaning around food. Global Food History, 2(2), 105-131. doi:10.1080/20549547.2016.1214896

Ray, K. (2016). The ethnic restaurateur. New York, NY: Bloomsbury.

Shah, N. (2001). Contagious divides: Epidemics and race in San Francisco's Chinatown. Berkeley, CA: University of California Press.

Schumpeter, J. (1942). Capitalism, socialism, and democracy. New York, NY: Harper.

Sin, C. H. (2002). Segregation and marginalization within public housing: The disadvantaged in Bedok New Town, Singapore. Housing Studies, 17(2), 267-288. doi:10.1080/02673030220123225

Singapore Hawker Entrepreneur Program. (n.d.). Singapore Hawker Academy. Retrieved from http://www.singaporehawkeracademy.com/

Slotkin, R. (1973). Regeneration through violence: The mythology of the American frontier, 1600-1860. Norman, OK: University of Oklahoma Press.

Straits Times. (2016, October 28). Hawker Centre 3.0: Whipping up tasty ideas.

Tagliacozzo, E. (2013). The longest journey: Southeast Asians and the pilgrimage to Mecca. Oxford, UK: Oxford University Press.

Tam, A. (2017). Singapore hawker centers: Origins, identity, authenticity, and distinction. Gastronomica, 17(1), 44-55.doi:10.1525/ gfc.2017.17.1.44

Tan, J. (2016, Sep. 16). What happened to the global schoolhouse? University World News. Retrieved from http://www.universityworldnews. com/article.php?story $=20160913131137765$

Tarulevicz, N. (2013). Eating her curries and kway: A cultural history of food in Singapore. Champaign, IL: University of Illinois Press.

Tarulevicz, N. (2015). I had no time to pick out the worms: Food adulteration in Singapore, 1900-1973. Journal of Colonialism and Colonial History, 16(3), 1-24.

Tarulevicz, N. (2016). Food safety as culinary infrastructure in Singapore, 1920-1990. Global Food History, 2(2), 132-156. doi:10.1080/2054954 7.2016 .1207370

Velayutham. S. (2017). Races without racism? Everyday race relations in Singapore. Identities, 24(4), 455-473. doi:10.1080/107028 9X.2016.1200050

Warren, J. F. (1986). Rickshaw coolie: A people's history of Singapore, 1880-1940. Singapore: National University of Singapore Press. 
FORUM | HAWKERPRENEURS: HAWKERS, ENTREPRENEURSHIP, AND REINVENTING STREET FOOD IN SINGAPORE

Nicole Tarulevicz

Willis, J. M. (2017). Governing the living and the dead: Mecca and the emergence of the Saudi biopolitical state. American Historical Review, 122 (2), 346-370. doi:10.1093/ahr/122.2.346
Yeo, C. H. A. (2010). The soy sauce towkay: The story of Yeo Thian In, founder of Yeo Hiap Seng sauce factory in Singapore. Singapore: Imprint. 